\title{
The global financial crisis and its aftermath: a perspective from fiction
}

Article

Accepted Version

Arch, L. ORCID: https://orcid.org/0000-0002-6359-0058 (2021)

The global financial crisis and its aftermath: a perspective from fiction. Qualitative Research in Financial Markets, 13 (1). pp. 50-58. ISSN 1755-4179 doi: https://doi.org/10.1108/QRFM-062020-0099 Available at https://centaur.reading.ac.uk/91406/

It is advisable to refer to the publisher's version if you intend to cite from the work. See Guidance on citing.

To link to this article DOI: http://dx.doi.org/10.1108/QRFM-06-2020-0099

Publisher: Emerald Publishing Limited

All outputs in CentAUR are protected by Intellectual Property Rights law, including copyright law. Copyright and IPR is retained by the creators or other copyright holders. Terms and conditions for use of this material are defined in the End User Agreement.

\section{www.reading.ac.uk/centaur}

\section{CentAUR}

Central Archive at the University of Reading

Reading's research outputs online 
The Global Financial Crisis and Its Aftermath: A Perspective from Fiction

\begin{tabular}{|r|l|}
\hline Journal: & Qualitative Research in Financial Markets \\
\hline Manuscript ID & QRFM-06-2020-0099 \\
\hline Manuscript Type: & Short Note \\
\hline Keywords: & $\begin{array}{l}\text { global financial crisis in fiction, Crunch lit, finance fiction, finance and } \\
\text { knowledge }\end{array}$ \\
\hline
\end{tabular}

\section{SCHOLARONE \\ Manuscripts}




\section{The Global Financial Crisis and Its Aftermath: A Perspective from Fiction}

\section{Structured Abstract}

Purpose

Since the global financial crisis of 2007-09 academic research has paid considerable attention to understanding the nature of the crisis, its causes and consequences. This is not surprising given the scale and scope of the crisis. Much of this research has been undertaken within social science disciplines. At the same time, the crisis has also been the subject of fictionnovels, poetry and drama and there is also a small body of academic scholarship on fiction relating to the crisis (and on finance in fiction more generally). The purpose of this viewpoint article is to suggest that fiction can offer a new perspective on the global financial crisis and thereby enhance our understanding of it.

\section{Design/methodology/approach}

This exploration draws upon three works of post-crisis fiction: the 2009 play by David Hare, The Power of Yes: A Dramatist Seeks to Understand the Financial Crisis (hereafter The Power of Yes); Other People's Money, a novel by Justin Cartwright (2011); and Robert Harris's novel The Fear Index also published in 2011. Its approach is based on close readings of the three texts in question.

\section{Findings}

Finance fiction stimulates a reconceptualization of the global financial crisis as a crisis of innovation and technological change

\section{Originality}

This article is a viewpoint article. The originality lies in the author's interpretation of reading the global financial crisis through fiction.

\section{Keywords}

global financial crisis in fiction, Crunch lit, finance fiction, finance and knowledge, finance and art 


\section{Introduction}

The global financial crisis struck in 2007. Some of the most dramatic and iconic events of the crisis occurred in the following year with the bankruptcy of Lehman Brothers and the 'run' on, and taking into public ownership of, Northern Rock plc in the UK. In the thirteen or so years since the start of the crisis, a number of works of fiction have been published in which events relating to the financial crisis feature prominently. To illustrate its argument, this essay draws on three works of fiction published in the early years after the crisis. The first is David Hare's play The Power of Yes which opened at the Lyttelton Theatre, London in October 2009 which focuses on the crisis itself. The next is Other People's Money, a novel by Justin Cartwright published in 2011 which centres on the demise of a three-hundred-and-forty-yearold private bank, Tubal \& Co. Finally, reference is made to Robert Harris's 2011 novel, The Fear Index whose plot revolves around a hedge fund (Hoffman Investment Technologies) and its role in the Flash Crash of 6 May 2010 [1].

Since the Second World War finance has grown in prominence as a feature of British fiction according to Marsh (2015, p. 193); this may reflect the "peculiar powers that finance has gained in the postwar period" (Marsh, 2015, p. 204). More recently, since the crisis itself, finance fiction has often assumed genre forms. One example is the financial thriller [2]. Shaw posits the emergence of a new genre - 'Crunch lit' - whose function is both " to represent the 2007-8 financial crisis" but more broadly to disturb conventional interpretations of the crisis and, in doing so, undermine the idea of the "unrepresentability and confusing status of finance as a contemporary subject" (Shaw, 2015, p. 8 and pp. 16-17). Crosthwaite suggests the bifurcation of financial novels towards either the genre novels or literary ones has been at work since the 1970s. Despite the growing interest in finance, Gupta (2015, pp. 461-462) asserts that the output of "crisis novels" has been rather modest. Moreover, that output has tended to be overlooked by literary critics.

The status of finance fiction since the crisis is therefore somewhat unsettled. This reflects the ambivalent relationship between the reader of finance fiction and the world being represented in it. Finance is a domain with which we feel on some level acquainted but is nevertheless strange. As Brusberg-Kiermeier, McKenzie and Schäbler (2019, p. 4) have observed in relation to Lucy Prebble's 2009 play ENRON, the financial dealings dramatized in that play are "to a certain degree familiar" but ones which we "cannot really fathom at the same time." 
Drawing on Shaw's insight $(2015$, p. 8) that Crunch lit offers "alternative representations" of events, this essay argues that post-crisis finance fiction stimulates a reconceptualization of the global financial crisis as a crisis of innovation and technological change [3]. It is based on close readings of the three texts in question.

\section{A Crisis of Innovation and Technological Change?}

If innovation is conceptualised as a process, a required input is new knowledge. Finance fiction is pre-occupied with the nature of knowledge. It draws attention to a disposition within finance towards two types of knowledge. First, finance venerates - even deifies knowledge which is rarefied, technical and abstract. Accordingly, we find references in the fiction to some of finance's most hallowed theories and models. In part three of The Power of Yes Masa Serdarevic (one of four journalists in the play - she is about to start working for the Financial Times) explains to the Author that "Myron Scholes invented a formula" (p. 9). The character 'Myron Scholes' then proceeds to explicate at a blackboard the Black-Scholes formula (a model developed by Scholes and Fisher Black in 1973 to price options) (pp. 8-11). Immediately after Scholes' explication, George Soros, addressing the audience, expresses incredulity that financiers believed that a model in itself could remove risk: "Looking back it seems amazing to me that anyone imagined they could eliminate risk by mathematical models" (p. 11).

In Other People's Money Julian Trevelyan-Tubal, chair of the three-hundred-andforty-year-old bank private bank Tubal and Co., pays Professor Kuhn, a Nobel laureate, \$7 million for an invention in the form of a theory and a model. Julian had observed the spellbinding effect of the inclusion of formulae in investment prospectuses on potential investors. One hedge fund had printed the formula for the standard normal distribution in a prospectus (which the author also does in the novel) to "lend credibility to their claim that, with the curve, the markets were knowable (...) How impressed the clients were to find that algebra (if it was algebra) had removed the uncertainty from markets" (p. 17). Julian proceeds to use the professor's theory and model to guide the investment decisions of his bank's hedge fund business, Lion Fortress Hedge Fund. So disastrous are the hedge fund's transactions that within a few years the bank has accumulated " $\$ 800 \mathrm{~m}$. of utterly useless and finely diced mortgages in territories they have never even visited" (15). The collapse of the hedge fund precipitates the demise and of Tubal and Co. itself. 
In the "clean, cerebral world" of finance (McDowell, 2011, p. 199) a quintessential symbol of cerebrality is the algorithm and an algorithm is at the heart of The Fear Index. Named VIXAL-4, it is an "autonomous machine-learning algorithm" (p. 117). It has been invented by Dr Alex Hoffman, founder of the hedge fund Hoffman Investment Technologies. Its name alludes to the $\mathrm{VIX}^{\circledR}$ Index $^{\circledR}$, a "market estimate of expected volatility of the S\&P 500 Index" [4]. It also connotes the terms 'viral' and 'virus' (a term even more evocative than usual in the context of the SARS-CoV-2 pandemic of 2020) and the concept of a 'computer virus'. It is suggestive of emotions, such as fear, sweeping through the financial markets like a highly infectious virus. Events in the novel culminate in the Flash Crash itself on 6 May 2010 with the narrator reporting that "The fear in the US markets was going viral, algorithms sniffing and sniping at one another along their fibre-optic tunnels as they struggled to find liquidity" (p. 364).

Hoffman's VIXAL-4 algorithm is a financial innovation; it is FinTech. It analyses Big Data from the internet. Its objective is to " isolate, measure, and factor into our market calculations the element of price that derives entirely from predictable patterns of human behaviour" " (p. 112). The specific aspect of human behaviour - or more accurately human emotion - that Hoffman wishes his algorithm to detect is fear, it being "the strongest human emotion, period" as well as being the emotion which is "driving the world as never before" (p. 114). It searches for "fear-related language" and seeks to understand its relationship with the financial markets (p. 262). These relationships then guide Hoffman Investment Technologies' investing decisions.

Immediately after the Flash Crash, VIXAL-4 continues - inexplicably - to trade, even after the hardware on which it resides has been destroyed:

LIN JU-LONG: It's still trading.

HUGO QUARRY: What?

LIN JU-LONG: VIXAL is still trading.

HUGO QUARRY: But it can't be. I just saw all the hardware burned to the ground.

LIN JU-LONG: Then it must have other hardware we don't know about. Something quite miraculous appears to have taken place (pp. 381-382).

VIXAL-4 is an embodiment of the leading edge of financial technology but may also be a reminder that of Arthur C. Clarke's 'law' that "any sufficiently advanced technology is indistinguishable from magic" (Clarke, 1999, p. 2). In the minutes and hours after the Flash 
Crash Hugo Quarry (Hoffman's business partner and CEO of Hoffman Investment Technologies) reflects upon VIXAL-4. His description of it evokes something at once magical, almost divine, but also menacing, like a miasma:

He pictured it [VIXAL-4] as a kind of glowing celestial digital cloud, occasionally swarming to earth. It might be anywhere - in some sweltering, potholed industrial zone stinking of aviation fuel and resounding to the throb of cicadas beside an international airport in South-East Asia or Latin America; or in a cool and leafy business park in the soft, clear rain of New England or the Rhineland; or occupying a rarely visited and darkened floor of a brand-new office block in the City of London or Mumbai or São Paulo; or even roosting undetected on a hundred thousand home computers. It was all around us, he thought, in the very air we breathed (p. 384).

The second type of knowledge to which finance is disposed is knowledge of the future and fiction draws attention to the tendency to privilege knowledge of the future over knowledge of the past. Its builds models or uses machine learning (VIXAL-4 in The Fear Index) which are by definition future-oriented, their purpose being to predict outcomes. In Other People's Money, Sir Harry Trevelyan-Tubal, former chairman of Tubal and Co. having suffered a stroke three years ago is now experiencing severe memory loss. He is emblematic of a world in which the past has been largely erased. Furthermore, knowledge of the past is disdained and eschewed. In The Power of Yes, the character, Leading Industrialist, remarks that "this is a world in which there is no past (...) that generation had an active memory (...) The new generation has no memory. I've learnt not even to talk about the eighties, because nobody knows what I'm talking about" (p. 12). Scott Rudmann, a private equity investor, opines that even though the global financial crisis had some parallels with the Savings and Loans scandal in the US in the 1980s, but "nobody seemed to remember the consequences" of that previous crisis (p. 25). Michael Milken had been completely forgotten (p. 27) [5]. Jon Cruddas MP, remarks of Tony Blair in a dialogue with the Announcer that he "doesn't believe in history. Doesn't think it matters. Doesn't think it exists” (p. 39) [6].

\section{Conceptions of Risk}

The domains of incomplete information of interest to finance are those of risk and uncertainty. Finance classifies the risks facing a company or investor as systematic and unsystematic and to use tools to measure and manage these. Specific risks fall into these two 
broad categories, for example, interest rate risk (as a systemic risk) or model risk, an unsystematic risk. Risks can be managed by avoiding the risk, accepting it, mitigating it, or transferring it. So interchangeable have the concepts of finance and risk become that in the 2013 report of the Parliamentary Commission on Banking Standards, Changing Banking for Good, Dr Peter Hahn posited (para. 679) that the core role and very purpose of banks was to manage risk: "Banks, however, are fundamentally risk management businesses; their business is to try to match risk and return on a daily basis. [...] the challenge is that it is very hard for many large businesses to change their risk profile very quickly, and a bank could take on unbelievable amounts of risk in a few moments."

Official enquiries into the causes of the global financial crisis have stressed the inability of financiers and financial institutions in the period before the crisis to quantify risk and manage it. The 2011 US government Financial Crisis Enquiry Report, for example, identified "dramatic failures of (...) risk management" (2011, xviii) as a contributory factor to the global financial crisis. Changing Banking for Good noted that "The complexity of the models used by banks, and the effort expended in building them, led to misplaced confidence in their value and a failure by banks and regulators to question their output sufficiently" (para. 88). This suggests that the techniques developed to quantify risk were inadequate.

This theme is portended in the fiction. Ronald Cohen ('a private equity pioneer') in The Power of Yes points to the narrow, self-referential view of risk that prevailed before the crisis:

When you model risk, you only model your own risk. You don't model for the whole system. Banks were only interested in their own position. At no point did any bank ask, 'What will happen if no one can borrow and no one can lend?' That was outside the model (p. 43).

A different perspective on risk is a sociological one. Giddens (1999, p. 4) makes the distinction between "external risk" and "manufactured risk." Manufactured risk, which are "new risk environments for which history provides us with very little previous experience," is an outcome of scientific and technological progress itself (1999, p. 4). "External risks" are those risks which in the past might have been "attributed to gods or God or nature," whereas the risks we tend to face now are those which are a product of " 'modernization' and 'progress' itself' (Yates and Beck, 2003, p. 4). Through this analytical frame, innovation in 
finance - including the application of theories and models - exemplifies "manufactured risk." In The Power of Yes, the Leading Industrialist points out that finance sees innovation and the process of technological change in the industry as a means of managing risk, rather than seeing those as generators of manufactured risks: "These securitised credit arrangements were a new invention, and they engendered a new level of hubris. They were so profitable that they made people believe, 'Oh, we've found a new answer to risk.' But they hadn't. Interesting, actually. The very opposite. They'd made risk worse" (p. 26).

Leech et al. posit a framework for understanding the dimensions of incomplete knowledge, which moves beyond risk, or even risk and uncertainty. They propose that there are four "idealized possible states of knowledge" (2010, pp. 42-44) and visualize these "states of knowledge" as follows:

[Figure 1 here]

Uncertainty is a state in which our knowledge about the probabilities we attach to possible outcomes is problematic, while ambiguity is a state in which our knowledge about possible outcomes is problematic. In a state of ignorance our knowledge about both outcomes and likelihoods is problematic and cannot be quantified. Finance is pre-occupied with risk and underappreciates uncertainty, ambiguity and ignorance. In the latter three states, our "analytic methods - such as risk assessment," may not be appropriate (Leach et al. 2010, p. 43).

While risk permeates finance, and financiers see essence of their role as managing risk, there is insufficient appreciation that "a risk society is a society where we increasingly live on a high technological frontier which absolutely no one completely understands and which generates a diversity of possible futures" (Giddens, 1999, p. 3). It is for this reason that Sebag Montefiore (cited in Giddens, 1999, p. 2) has suggested the metaphor of the financier as an "astronaut" operating at the "outer edges of the financial system" [7]. In The Fear Index, Hoffman is the astronaut. His algorithm VIXAL-4 uses machine learning to guide its investing decisions. It is able, Hugo Quarry observes, to "learn what to look for, so to speak, and then teach itself what to look for next" (p. 290) seeing "a pattern in events that we can't discern" (p. 266). 


\section{Art as a Countervail}

Finance fiction uses art to foreground incomplete knowledge. In Other People's Money and The Power of Yes works of visual art intensify suggest uncertainty, ambiguity and even ignorance. In Other People's Money, a painting by Henri Matisse French Window at Collioure, acts as a metaphor for the limits of knowledge [8]. The narrator describes Sir Harry Trevelyan-Tubal gazing at the painting thus:

Last night Harry sat in front of it for an hour. It's called French Window at Collioure and is three panels of colour, but still clearly a window with a stone frame. The stone of the window is in lilac, the shutter - if it is a shutter - is of a wood bleached by exposure to the sun and on one side of that is the lintel of greeny grey. It could be seen simply as beautiful blocks of colour. But in the middle, where you would expect the view beyond, there is a large rectangle of darkness, absolutely black (p. 110).

In The Fear Index, the protagonist Alex Hoffman's wife, Gabrielle, is an artist. Her works consist of many sheets of crystal-clear glass or Perspex stacked on their edge to form a cube (p. 39). She traces electronic images of the human body onto each sheet which are then stacked together. Leclerc, inspector of the Geneva Police Department, describes the effect of one such work thus: "Viewed from the side it had depth, but as one shifted one's perspective to the front it seemed to dwindle, then vanish entirely. He could not make out whether it was finished or not" (p. 39).

Writing and writers features prominently in the fiction. The symbolic character in Other People's Money is the writer or more precisely, "playwright and actor manager" (p. 20) Artair MacCleod. He is the former husband of Sir Harry's wife, Fleur and now lives off an annual grant made by the Tubal family trust. Throughout the novel a lofty project consumes him: to write and produce "a five-hour play based on the life and novels of Flann O'Brien" (p. 20). Artair is a symbol of the power of art. Fleur notes that "has done something heroic: he has kept faith with art and its power" (p. 222). While financial institutions are often associated with processes of transformation (they transform maturity and transform risk, for example) the novel suggests that is actually art which has that capacity: "The transformative power of art is a mystery to them. To Artair it is everything (...) a life lived in the pursuit of art is the only one worth living" (p. 120). Artists are countervails to financiers in part because they have a very different concept of truth. Artair epitomises this different conception in his 
belief that: "it is therefore the artist's single most important duty to show that truth is never at any one moment complete" and that "it is your duty to challenge this idea of a single reality" (p. 211 and p. 212).

While McDowell (2010, p. 197) refers to The Power of Yes not as fiction but as a "factional drama", its fictionality is emphasised through the device of a play-within-a-play (pp. 42-56). Using chalk and a blackboard as his props, the character Howard Davies re-tells the global financial crisis as a drama in five acts, titled $S-L-U-M-P$ (sub-prime, liquidity, unravelling, meltdown, and pumping). Act One begins on the day housing market collapses (p. 42) and ends at Act Five with "bodies all over the stage" (p. 56). One fatality is our confidence in the market itself: "Markets are not decent and they're most certainly not wise. That idea is over. It's dead. It's lying dead on the stage" (p. 67). With its five-act structure $S$ $L-U-M-P$ suggests the tragic dimension of the global financial crisis. It is however a tragedy without a resolution. As Davies reaches Act Five of his re-telling, the author asks whether there will now be "a reckoning." Davies responds ambiguously, smiling: "Well, that's a very good question. What a good question. Is there a reckoning?” (p. 57).

\section{Conclusion}

Fiction points us to conceptualize the global financial crisis its aftermath as a crisis of innovation and technological change. Such change leads to the expansion of manufactured risk (Giddens, 1999, p. 4). While there has been a robust and effective regulatory response to the crisis, it could be argued that it has not addressed the broader issue of the growth of manufactured risk in the context of enormous technological change. This issue is not unique to companies in banking and financial services; it is, for example, particularly pertinent to firms in the online platform and digital advertising sectors - including the Big Tech companies. As Giddens observed many years ago "We do not currently possess institutions which allow us to monitor technological change," and accordingly "such change is completely outside the democratic system" (1999, p. 6).

\section{Notes}


1. "On May 6, 2010, the prices of many U.S.-based equity products experienced an extraordinarily rapid decline and recovery. That afternoon, major equity indices in both the futures and securities markets, each already down over $4 \%$ from their prior-day close, suddenly plummeted a further $5-6 \%$ in a matter of minutes before rebounding almost as quickly." See: Findings Regarding the Market Events of May 6, 2010: Report of the Staffs of the CFTC and SEC to the Joint Advisory Committee on Emerging Regulatory Issues, 30 September 2010, p. 1.

2. A thriller is "A kind of popular novel in which a protagonist endangered by a criminal or otherwise sinister conspiracy is followed through heroic adventures made up of flight, pursuit, capture, and escape" (Baldick, C., 2015). An example of a post-crisis financial thriller is City of Thieves by Cyrus Moore. The strapline on the cover is, "The bestselling City thriller." The Fear Index has characteristics of a thriller.

3. The conventional distinction between invention and innovation is that: "Invention is the discovery or creation of a product or process, whereas innovation is the process through which inventions and ideas become a business or operational reality," (Needle, 2015, p. 354). While innovation and technology are sometimes regarded as interchangeable, technological change is a much broader concept. Bruland (2001, p. 14) for example argues: "Of course technology does involve hardware (machines, tools, infrastructure) and technique (in the sense of routines of technical practice), but it also involves at least two other primary dimensions, namely knowledge and organisation, both of which are social phenomena. (...) the evolution of technologies involves complex social processes of conflict, negotiation, compromise, and adaptation, and technological change cannot be understood in isolation from these social dimensions. In these approaches, society is not seen as adapting to a deterministic process of technological change, but rather it is social values and decisions that shape the path of technological development."

4. "The VIX Index is intended to provide an instantaneous measure of how much the market thinks the S\&P 500 Index will fluctuate in the 30 days from the time of each tick of the VIX Index", available at: http://www.cboe.com/products/vix-index-volatility/vix-options-andfutures/vix-index/vix-faqs\#1 (accessed 20 March 2020).

5. Michael Milken was granted a full and unconditional pardon for his convictions by President Donald J. Trump on 18 February, 2020. See: "Pardons Granted by President 
Donald Trump," The United States Department of Justice, available at:

https://www.justice.gov/pardon/pardons-granted-president-donald-trump (accessed 8 May 2020).

6. Jon Cruddas was Labour Member of Parliament (MP) for the constituency of Dagenham from 2001 to 2010 and from 2010 to the present MP for Dagenham and Rainham. Tony Blair was Prime Minister of the United Kingdom from 1997 to 2007.

7. This description is cited in Giddens $(1999$, p. 2) but the source is not given.

8. Painted in 1914, Porte-fenêtre à Collioure is held at the Musée National d'Art Moderne in the Centre Georges-Pompidou, 


\section{References}

Baldick, C. (2015), The Oxford Dictionary of Literary Terms, $4^{\text {th }}$ ed., Oxford University Press, Oxford.

Bruland, K. (2001), “Technology”, Stearns, P. N. (Ed.), Encyclopedia of European Social History Vol. 2: Processes of Change/Population/Cities/Rural Life/State \& Society, available at:

https://link.gale.com/apps/doc/CX3460500068/GVRL?u=rdg\&sid=GVRL\&xid=542f 056a (accessed 20 May 2020).

Brusberg-Kiermeier, S., McKenzie, J. and Schäbler, D. (2019), "Fear and Anxiety in Contemporary Drama and Performance: An Introduction”, Journal of Contemporary Drama in English, Vol. 7 No. 2, pp. 1-11.

Cartwright, J. (2012), Other People’s Money, Bloomsbury Publishing plc, London.

Clarke, A. C. (1999), Profiles of the Future: An Inquiry into the Limits of the Possible, Indigo, London.

Findings Regarding the Market Events of May 6, 2010: Report of the Staffs of The CFTC and SEC to the Joint Advisory Committee on Emerging Regulatory Issues, 30 September 2010, available at:

https://www.cftc.gov/sites/default/files/idc/groups/public/@otherif/documents/ifdocs/ staff-findings050610.pdf (accessed 19 May 2020).

Giddens, A. (1999), "Risk and Responsibility”, The Modern Law Review, Vol. 62 No. 1, pp. $1-10$.

Gupta, Suman. (2015), "Crisis of the Novel and the Novel of Crisis", Canadian Review of Comparative Literature, Vol. 42 No. 4, pp. 454-467.

Hare, D. (2009), The Power of Yes: A Dramatist Seeks to Understand the Financial Crisis, Faber and Faber Limited, London.

Harris, R. (2019), The Fear Index, Arrow Books, London. 
Leach, M., Scoones, I. and Stirling A. (2010), Dynamic Sustainabilities, available at: https://eva.fcs.edu.uy/pluginfile.php/69180/course/section/7664/Dynamic\%20Sustain abilities_\%20_Tech\%20-\%20Melissa\%20Leach.pdf (accessed 11 March 2020).

Marsh. N. (2015), "Finance, Fiction, and the Genre of a World Economy”, James, D. (Ed.) The Cambridge Companion to British Fiction Since 1945, available at: https:/www.cambridge.org/core/books/cambridge-companion-to-british-fiction-since1945/4CCD63C160120A042885F24E4F836F10 (accessed 22 April 2020), pp. 192206.

McDowell, L. (2011), "Making a Drama out of a Crisis: Representing Financial Failure, or a Tragedy in Five Acts", Transactions of the Institute of British Geographers, Vol. 36, pp. 193-205.

Moore, C. (2010), City of Thieves, Sphere, London.

National Commission on the Causes of the Financial and Economic Crisis in the United States (January 2011), Financial Crisis Inquiry Report: Official Government Edition, available at: https://fcic-static.law.stanford.edu/cdn_media/fcicreports/fcic_final_report_full.pdf(accessed 11 March 2020).

Needle, D. (2015), Business in Context: An Introduction to Business and Its Environment. $6^{\text {th }}$ ed., Cengage Learning EMEA, Andover.

Nelson, C. (2008), "You Can't Write a Social Novel After September 11", New Writing: The International Journal for the Practice and Theory of Creative Writing, Vol. 5 No. 1, pp. 50-64.

Parliamentary Commission on Banking Standards (June 2013), Changing Banking for Good Volume II: Chapters 1 to 11 and Annexes, together with Formal Minutes, available at: https://www.parliament.uk/documents/banking-commission/Banking-final-report-volii.pdf (accessed 12 March 2020).

Shaw, K. (2015), Crunch Lit, Bloomsbury Academic, London. 
Yates, J. and Beck, U. (2003), "Interview with Ulrich Beck: On Fear and Risk Society", available at: https://hedgehogreview.com/issues/fear-itself/articles/interview-withulrich-beck (accessed 7 May 2020). 


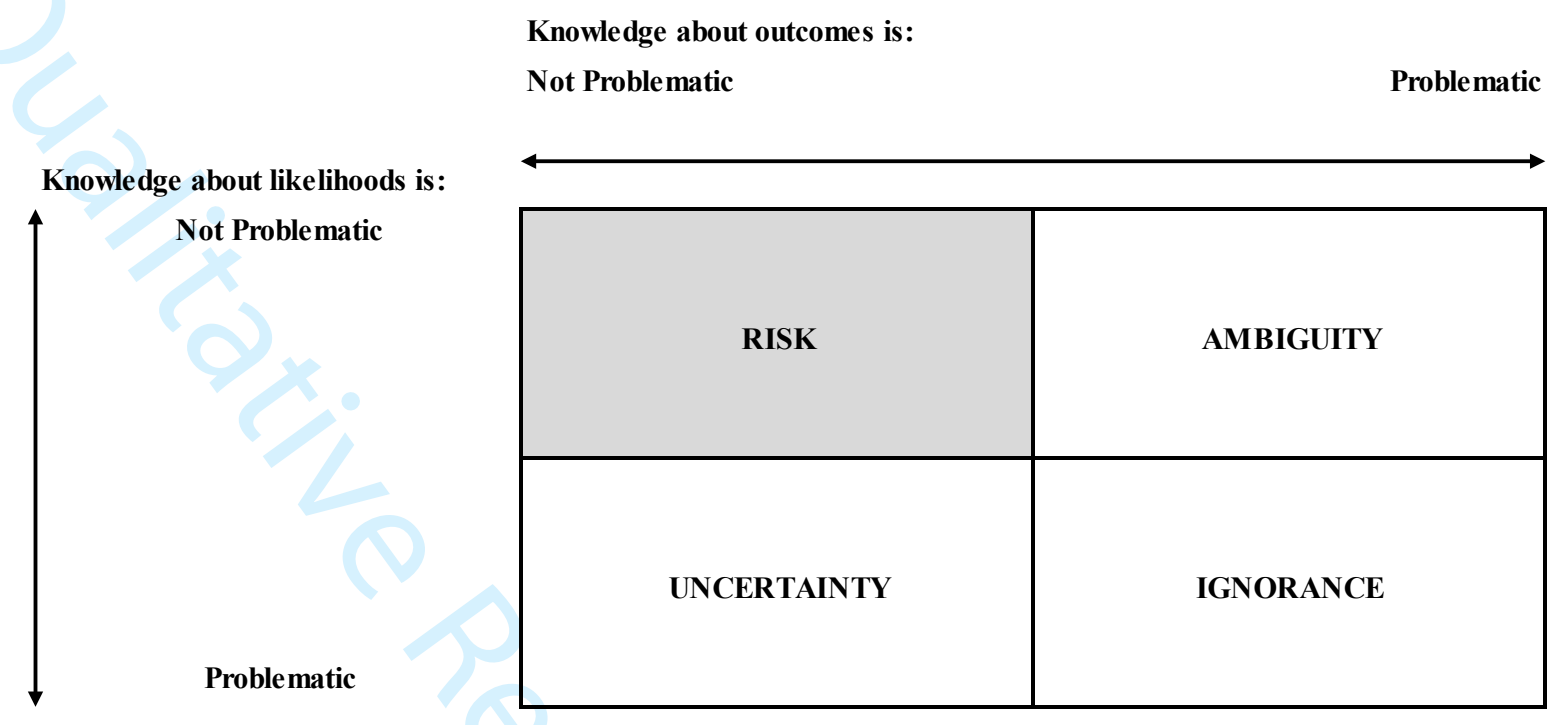

Figure 1: Ideal types of incomplete knowledge. Source: Leach et al., Figure 3.4. 